\title{
Evaluation of the Role of Vitamin C in Protection Against Topiramate Induced Nephrotoxicity in Adult Male Albino Rats
}

\author{
HALA H.M. MOSSALAM, M.D.* and MOHAMMAD M. EL-SHAWWA, M.D.** \\ The Departments of Anatomy \& Embryology* and Physiology**, Faculty of Medicine for Girls, Al-Azhar University
}

\begin{abstract}
Background: Topiramate is a drug used to treat seizures in patients with epilepsy, however, kidney damage may result after its long-term use. The mechanisms of damage are variable and can affects all renal cellular components.

Aim of Study: Treatment with an antioxidant, such as vitamin $\mathrm{C}$, may help prevent this renal damage. In this study, we used histological, ultrastructural, and biochemical approaches to detect the renal affection caused by topiramate treatment and to evaluate the role of vitamin $\mathrm{C}$ in protection against topiramate-induced nephrotoxicity.
\end{abstract}

Material and Methods: Forty adult male albino rats treated daily for six weeks and divided equally to four groups: Group I (control group), group II supplemented orally with vitamin $\mathrm{C}(10 \mathrm{mg} / \mathrm{kg} /$ day $)$, group III treated orally with topiramate $(100 \mathrm{mg} / \mathrm{kg} / \mathrm{day})$, and group IV received vitamin C $(10 \mathrm{mg} /$ $\mathrm{kg} /$ day) 2 hours prior to topiramate $(100 \mathrm{mg} / \mathrm{kg} /$ day $)$ treatment.

Results: Examination of the kidney tissue of group III showed distortion of the renal glomeruli and tubules. In addition, topiramate significantly elevated the levels of serum urea, creatinine, lipocalin, indoxyl sulphate, and tissue malondialdehyde (MDA), and caused significant reduction in tissue superoxide dismutase (SOD) and catalase (CAT). However, group IV showed improvement in the renal glomeruli and tubules with significant improvement in serum urea, creatinine, lipocalin, indoxyl sulphate and tissue oxidative stress markers.

Conclusion: The data presented in this work shows that topiramate may be a toxic therapeutic agent however, vitamin $\mathrm{C}$ supplementation may aid in protection against topiramateinduced nephrotoxicity.

Key Words: Topiramate - Vitamin C, Renal-Transmission electron microscope.

\section{Introduction}

IN patients with epilepsy, topiramate is used as an initial monotherapy or as part of a polytherapy [1] Topiramate is used as anticonvulsant, analgesic, and mood-stabilizing agent [2] . Oxidative stress can cause chemical modification or damage to proteins, lipids, carbohydrates, and nucleotides [3]

Correspondence to: Dr. Hala H.M. Mossalam

E-Mail: halahamed1000@gmail.com
Vitamin C (ascorbic acid) can directly scavenge oxygen free radicals with and without an enzyme catalyst [4]. It aids in the reactivation of other antioxidants [5] and protects critical macromolecules from oxidative damage [6]. The current study was carried out to investigate the renal lesions caused by topiramate and to evaluate the probable reno-protective and antioxidant effects of vitamin $\mathrm{C}$ against topiramate-induced nephrotoxicity in male rats. According to our research in the literature, there is no published data showing the antioxidant effects of vitamin $\mathrm{C}$ on topiramate-induced nephrotoxicity in male albino rats.

\section{Material and Methods}

\section{Animals:}

Forty adult male albino rats obtained from Theodor Bilharz-Institute (Giza, Egypt), with weights ranging from $150 \mathrm{~g}-200 \mathrm{~g}$, were included in the study. The animals were housed in the animal facility at the Faculty of Medicine for Girls, AlAzhar University and allowed free access to water. Animals were not exposed to pain or stress and animal manipulation was performed with maximal care and hygiene. The experiment was performed between September 2019 - March 2020 under protocols approved by the local Institutional Animal Ethics Committee of Al-Azhar University.

\section{Drugs:}

Vitamin C was purchased from ADWIC and topiramate was purchased from Delta Pharm (10 th of Ramadan City, Egypt).

\section{Experimental design:}

Rats were treated daily for six weeks and divided into equal four groups.

- Group I: The control received no medication.

- Group II: The vitamin C group received vitamin $\mathrm{C}(10 \mathrm{mg} / \mathrm{kg} /$ day $)$ orally by oral gavage according 
to [7]. Adjustment of rat dose was according to Paget and Barnes [8] formula.

- Group III: The topiramate treated group was treated by topiramate $(100 \mathrm{mg} / \mathrm{kg} /$ day $)$ orally by oral gavage according to [9]. Adjustment of rat dose was according to Paget and Barnes [8] formula.

- Group IV: This group received the same dose of vitamin $\mathrm{C}$ as in group II 2 hours before treatment with topiramate as in group III.

\section{Collection of blood and tissue samples:}

By the end of experimental period, blood samples were collected under light ether anesthesia and centrifuged to obtain sera which was immediately stored at $-80^{\circ} \mathrm{C}$ until use. Both kidneys of each rat were dissected out and washed immediately with saline. One kidney was taken for estimation of oxidative stress markers and light microscopy while the other was prepared for a transmission electron microscopic study.

Histopathological preparation for light microscopic examination:

Kidney specimens were collected from all groups, fixed then processed to be stained with hematoxylin and eosin (H\&E) [10].

Preparation for Transmission Electron Microscopy (TEM):

Kidney specimens were fixed in $2 \%$ glutaraldehyde and post-fixed in $1 \%$ osmium tetroxide. Specimens were then dehydrated and embedded in epoxy resin. Ultrathin sections were prepared according to [11] then examined and photographed using a transmission electron microscope (Joel $1010 \mathrm{Jem}$ ) at the Regional Center for Mycology and Biotechnology (RCMB)- Al-Azhar University.

\section{Preparation of tissue homogenate:}

Preparation of tissue homogenate was done by homogenizing kidney tissue in cold $0.9 \% \mathrm{NaCl}$ to obtain at $10 \%$ solution using Ultra Turrax tissue homogenizer. After centrifugation ( $10 \mathrm{~g}$ for $15 \mathrm{~min}$ ), the clear supernatant fluids at $4{ }^{\circ} \mathrm{C}$ were used in biochemical estimations.

\section{Renal function assessment:}

Renal function markers, including urea, creatinine, lipocalin, and indoxyl sulphate were estimated spectrophotometrically using commercially diagnostic kits. Serum urea and creatinine levels were analyzed by the calorimetric technique described in [12], level of indoxyl sulfate was determined by ELISA [13], and serum lipocalin level by ELISA [14].

\section{Assay of renal tissue biomarkers:}

In renal tissue homogenates, lipid peroxidation was estimated and expressed as malondialdehyde (MDA) production following the method of [15] Superoxide dismutase (SOD) activity was estimated using ELISA [16]. Catalase (CAT) activity was estimated using the method of [17]

\section{Statistical analysis:}

Data was collected, charted, and analyzed using a statistical package for social sciences (Windows version 18 SPSS Inc., Chicago, Illinois, USA) [18] The contrast parameter values (mean \pm SD) among all groups were carried out using analysis of variance test followed by Tukey's multiple comparison test. The level of significance was defined as a $p$ value less than 0.05 .

\section{Results}

\section{Histopathological results:}

Light microscopic examination of the renal cortices of the control and vitamin $\mathrm{C}$ treated albino rats showed a normal histological structure (Fig. $1 \mathrm{~A}, \mathrm{~B})$. As a result, both groups (group I and group II) were considered as one control group (group C) during electron microscope examination. The renal cortex occupied by renal corpuscles formed of glomeruli which surrounded by proximal convoluted tubules (PCTs), distal convoluted tubules (DCTs), and interstitial tissue. Each corpuscle was formed of glomerulus and double-walled Bowman's capsule. Bowman's capsule is formed of visceral and parietal layers with a narrow glomerular filtration space between them. PCTs were lined with three to five layers of large cuboidal cells with rounded vesicular nuclei and acidophilic cytoplasm. DCTs were lined with small cuboidal cells with wide lumen (Fig. 1A,B).

However, examination of the renal cortex of group III showed distortion of the renal glomeruli which lost their appearance due to irregularity of glomerular capillary tuft. Some glomeruli appeared hypertrophied while other glomeruli appeared atrophied with wide glomerular spaces. Cells of renal tubules of PCTs and DCTs revealed dense pyknotic nuclei with cytoplasmic vacuolation. There was exfoliated cellular debris in the lumen of some tubules along with congestion and dilation of the peritubular blood vessels (Fig. 1C).

The renal cortex of group IV showed clear signs of improvement in the glomeruli, PCTs and DCTs, except for the presence of a of cellular debris in the tubular lumina along with mild blood capillary congestion (Fig. 1D). 

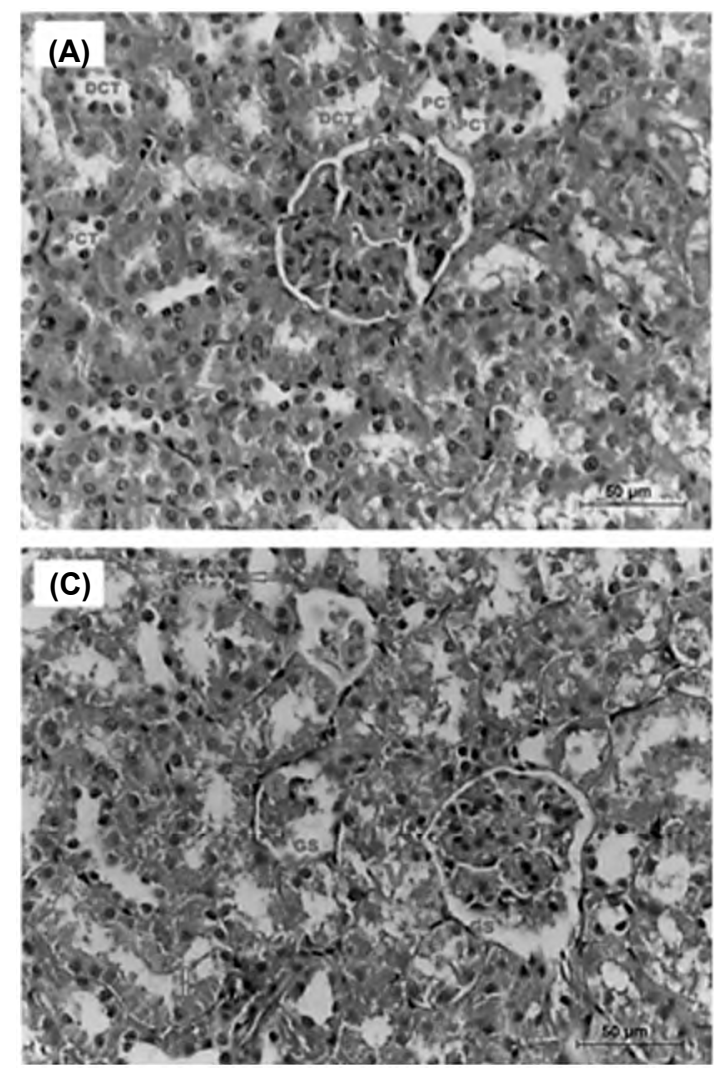
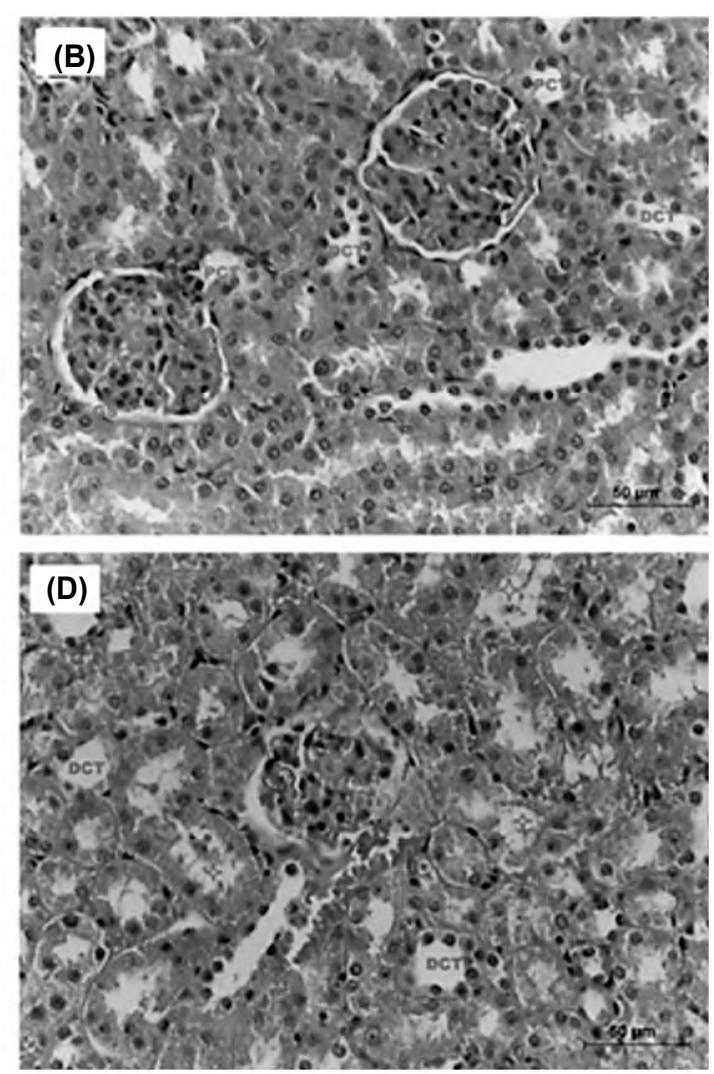

Fig. (1):

(A): Light photomicrography of the renal cortex of group C showing glomerular capillaries (G), glomerular space (GS), PCT with brush border containing vesicular nucleus and distal convoluted tubules (DCT) with wide lumen (H\&E x 400 magnification).

(B): Group II showing glomeruli (G), glomerular space (GS), proximal convoluted tubules (PCT) and distal convoluted tubules (DCT) (H\&E x 400 magnification).

(C): Group III showing distorted glomeruli (G), wide glomerular spaces (GS), vacuolated (v) tubules with exfoliated cellular debris (star) and congested capillaries (arrows) (H\&E x 400 magnification).

(D): Group IV showing glomeruli (G), proximal convoluted tubules (PCT), distal convoluted tubules (DCT) cellular debris (star) and mild capillaries congestion (arrows) (H\&E x 400 magnification).

\section{Transmission electron microscopic examination:}

Electron microscope examination of ultrathin sections of group $\mathrm{C}$ showed that glomeruli were composed of anastomosing blood capillaries lined by endothelial cells resting on a thin regular glomerular basement membrane. Glomerular blood capillaries were surrounded by podocytes. Each podocyte had large irregular euchromatic nucleus, primary and secondary processes which were terminated by foot processes that rested on thin glomerular basement membrane. The glomerular filtration barrier was composed of endothelial cells, a thin regular glomerular basement membrane and fenestrated secondary foot processes. Mesangial cells with surrounding mesangial matrix had irregular darkly-stained nuclei and scanty cytoplasm between glomerular blood capillaries (Fig. 2A).

In group III, the glomerular capillaries were congested, dilated filled with red blood cells (RBCs) with thickened irregular glomerular basement membrane. Podocytes revealed small, less intended nuclei with a less electron-lucent cyto- plasm and widening of their primary foot processes. Marked distortion of secondary foot processes with fragmentation, fusion, or even complete loss in extensive zones forming smooth structures. In addition, extensive mesangial matrix deposition around the mesangial cells was evident (Fig. 2B).

In group IV, the glomeruli had a well-preserved glomerular capillary with a glomerular basement membrane of average thickness, however, in a few areas it appeared thickened and irregular. Podocytes appeared nearly unaffected with normal primary and secondary foot processes. Mesangial cells appeared mostly normal; however, deposition of the mesangial matrix was observed (Fig. 2C).

In group C, PCT cells had euchromatic, basal, rounded nuclei resting on thin basement membranes. The cytoplasm contained rough endoplasmic reticulum, smooth endoplasmic reticulum, a few lysosomes and numerous rounded or elongated mitochondria. The apical surfaces of PCT had apical closely packed microvilli projecting within 
their narrow lumen forming their characteristic brush border (Fig. 2D). In group III, PCT cells had pyknotic nuclei, cytoplasmic vacuolation, swollen mitochondria, multiple lysosomes, and distorted apical microvilli (Fig. 2E). In group IV, PCT cells showed nearly normal nuclei, swollen mitochondria with many lysosomes, and closely packed microvilli (Fig. 2F).
In group C, DCT cells showed rounded euchromatic nuclei and numerous elongated mitochondria with a few microvilli (Fig. 2G). In group III, DCT cells had electron dense cytoplasm enclosing deformed nuclei with swollen mitochondria, and destructed apical microvilli (Fig. 2H). In group IV, DCT had regular-shaped cells with euchromatic nuclei and elongated mitochondria. (Fig. 2I).
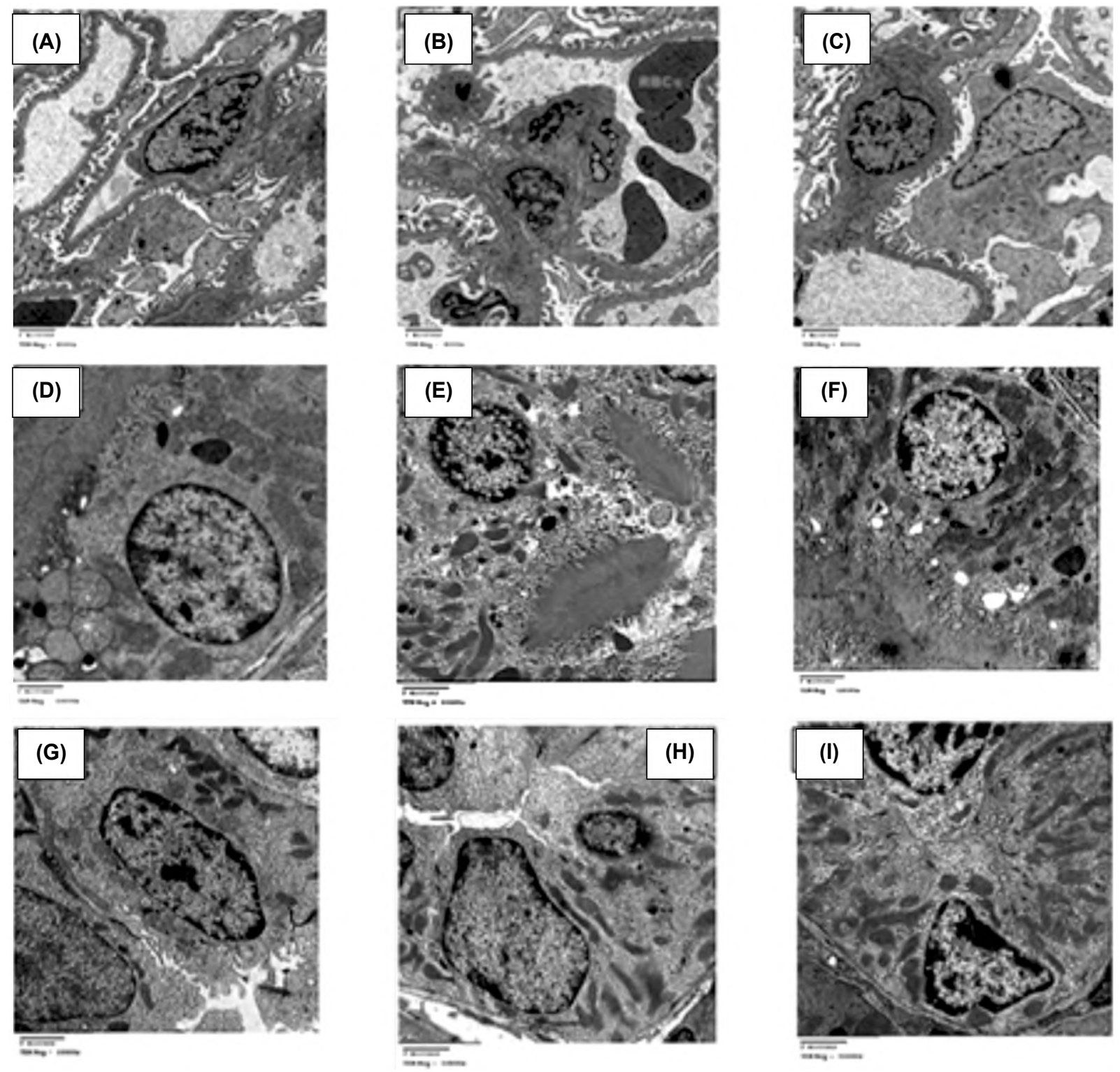

Fig. (2):

(A): Electron micrography of the renal corpuscles of group C showing glomerular capillaries (C), podocytes (P), fenestrations (arrows), and mesangial cells (M) (TEM Mag x 8000).

(B): Group III, showing glomerular capillary filled with (RBCs), thickened glomerular basement membrane (BM), mesangial cells with extensive mesangial matrix, and fusion of podocyte's foot processes of (arrows) (TEM Mag x 8000).

(C): Group VI, showing glomerular capillaries (C), podocyte (P), feet processes (arrows), and mesangial cells (M) (TEM Mag x8000).

(D): Group C, PCT cells show nucleus (N), lysosomes (L), mitochondria (M), and apical numerous microvilli (MV) (TEM Mag x10000).

(E): Group III showing PCT cells that have pyknotic nuclei (N), swollen mitochondria (arrow), and distorted microvilli (MV) (TEM Mag $\mathrm{x} 10000)$.

(F): Group VI showing PCT cells with nearly normal nuclei (N), mitochondria (M), numerous lysosomes (L), and microvilli (MV) (TEM Mag $\mathrm{x} 10000)$.

(G): Group C showing a DCT cell with a euchromatic nucleus (N), and mitochondria (M) (arrows) (TEM Mag x10000).

(H): Group III showing a DCT cell nucleus (N) and destructed apical microvilli (arrow) (TEM Mag x10000).

(I) : Group IV showing a DCT cell nucleus (N) and mitochondria (M) (arrows) (TEM Mag x10000). 


\section{Biochemical results:}

Topiramate treatment in group III resulted in an obvious deterioration in kidney functions as indicated by the significant elevation of blood urea, creatinine, lipocalin, and indoxyl sulphate if compared to group I and group II. In (group IV) there was significant improvement towards normal levels when compared to topiramate treated rats (group III). While it was possible for serum urea to reach normal levels, other parameters did not reach normal ranges of concentration when compared to both control and vitamin $\mathrm{C}$ administered rats (Table 1).

\section{Oxidative stress markers results:}

In group III, there was a significant elevation in tissue MDA associated with a significant reduction in tissue SOD and CAT if compared to group I and group II. On the other hand, in group IV there was a significant decrease in tissue MDA and increase of tissue SOD and CAT if compared to the topiramate treated group. However, this improvement could not reach a normal level if compared to both control and vitamin $\mathrm{C}$ administered rats (Table 2).

Table (1): Effect of vitamin C administration on Serum urea (mg/ml), creatinine ( $\mathrm{mg} / \mathrm{ml})$, lipocalin ( $\mathrm{g} / \mathrm{ml}$ ) and indoxyl sulfate $(\mathrm{mg} / \mathrm{l})$ in topiramate treated rats.

\begin{tabular}{|c|c|c|c|c|c|c|}
\hline \multirow[b]{2}{*}{ Parameters } & \multirow{2}{*}{$\begin{array}{c}\text { Group (I) } \\
\text { Mean } \pm \text { S.E.M }\end{array}$} & \multirow{2}{*}{$\begin{array}{c}\text { Group (II) } \\
\text { Mean } \pm \text { S.E.M }\end{array}$} & \multirow{2}{*}{$\begin{array}{c}\text { Group (III) } \\
\text { Mean } \pm \text { S.E.M }\end{array}$} & \multirow{2}{*}{$\begin{array}{c}\text { Group (IV) } \\
\text { Mean } \pm \text { S.E.M }\end{array}$} & \multicolumn{2}{|c|}{ ANOVA } \\
\hline & & & & & $\mathrm{F}$ & $p$-value \\
\hline Serum urea $(\mathrm{mg} / \mathrm{ml})$ & $38.2 \pm 3.1$ & $33.7 \pm 2.8$ & $87.7 \mathbf{a}^{\prime} \mathbf{b} \pm 5.1$ & $46.6^{\mathbf{a}^{\prime} \mathbf{b}^{\prime} \mathbf{c} \pm 3.6}$ & 8.2 & 0.002 \\
\hline Serum creatinine $(\mathrm{mg} / \mathrm{ml})$ & $0.17 \pm 0.01$ & $0.18 \pm 0.01$ & $1.1^{\mathbf{a}} \mathbf{b}_{ \pm 0.09}$ & $0.29 \mathrm{c} \pm 0.01$ & 9.7 & 0.001 \\
\hline Serum lipocalin ( $\mathrm{g} / \mathrm{ml}$ ) & $1.2 \pm 0.09$ & $1.4 \pm 0.1$ & $6.1 \mathbf{a}^{\prime} \mathbf{b} \pm 0.58$ & $2.2^{\mathbf{a}} \mathbf{b}^{\prime} \mathbf{c} \pm 0.16$ & 7.09 & 0.003 \\
\hline Indoxyl sulfate $(\mathrm{mg} / \mathrm{l})$ & $0.99 \pm 0.09$ & $0.84 \pm 0.07$ & $3.9 \mathbf{a}^{\prime} \mathbf{b} \pm 0.34$ & $1.7 \mathbf{a}^{\prime} \mathbf{b} \mathbf{c}_{ \pm} \mathbf{c}_{0.07}$ & 6.9 & 0.004 \\
\hline
\end{tabular}

a: Significant values compared to control.

b: Significant values compared to vitamin $\mathrm{C}$ administered group.

c: Significant values compared to topiramate treated group.

Significant values when $p<0.05$, using one-way ANOVA followed by Tukey's multiple comparison test.

Table (2): Effect of vitamin C administration on tissue MDA (nmol/g tissue), SOD ( $/ \mathrm{g}$ ssue) and CAT ( treated rats.

\begin{tabular}{|c|c|c|c|c|c|c|}
\hline \multirow[b]{2}{*}{ Parameters } & \multirow{2}{*}{$\begin{array}{c}\text { Group (I) } \\
\text { Mean } \pm \text { S.E.M }\end{array}$} & \multirow{2}{*}{$\begin{array}{c}\text { Group (II) } \\
\text { Mean } \pm \text { S.E.M }\end{array}$} & \multirow{2}{*}{$\begin{array}{c}\text { Group (III) } \\
\text { Mean } \pm \text { S.E.M }\end{array}$} & \multirow{2}{*}{$\begin{array}{c}\text { Group (IV) } \\
\text { Mean } \pm \text { S.E.M }\end{array}$} & \multicolumn{2}{|c|}{ ANOVA } \\
\hline & & & & & $\mathrm{F}$ & $p$-value \\
\hline Tissue MDA (nmol/g tissue) & $7.03 \pm 0.68$ & $6.7 \pm 0.81$ & $31.6 \mathbf{a}^{\prime} \mathbf{b} \pm 2.22$ & 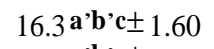 & 6.2 & 0.009 \\
\hline Tissue SOD ( Kg-issue) & $3.5 \pm 0.32$ & $4.01 \pm 0.24$ & $1.06 \mathbf{a}^{\prime} \mathbf{b} \pm 0.08$ & $2.70^{\mathbf{a}} \mathbf{b}^{\prime} \mathbf{c} \pm 0.13$ & 3.5 & 0.013 \\
\hline Tissue CAT ( lg missue) & $119.15 \pm 3.1$ & $123.5 \pm 4.5$ & $56.4 \mathbf{a}^{\prime} \mathbf{b} \pm 5.4$ & $99.9^{\mathbf{a}} \mathbf{b}^{\prime} \mathbf{c}^{ \pm} 1.3$ & 10.4 & 0.000 \\
\hline
\end{tabular}

a: Significant values compared to control.

b: Significant values compared to vitamin $\mathrm{C}$ administered group.

c: Significant values compared to topiramate treated group.

Significant values when $p<0.05$, using one-way ANOVA followed by Tukey's multiple comparison test.

\section{Discussion}

In this study topiramate treatment once daily for six weeks in adult male albino rats resulted in renal damage as evidenced from both microscopic and biochemical results. Our data demonstrated that the damage observed in the renal corpuscles and tubules might reflect the direct toxic effects of topiramate on renal tissue. This damage was manifested as atrophy of renal corpuscles, widening of glomerular spaces, thickening with irregularity of the glomerular basement membrane, the fusion of foot processes of podocytes with obliteration of filtration slits, and mesangial matrix deposition.
These histopathological changes due to topiramate were confirmed by the significant increase in serum urea and creatinine, significant decrease in antioxidant enzymes (CAT \& SOD) activities, and an elevated level of MDA in kidney tissue. These findings agreed with [19] who noted that topiramate caused similar histopathological and biochemical alterations in kidney tissue of mice with elevation in the urea level that contributed to renal failure. In this study, topiramate resulted in thickened glomerular basement membrane which might be explained by Hotta et al. [20] who mentioned that damage glomerular basement membrane might result from overproduction of collagen fibers with 
glycoproteins deposition. Gibson and Skett, [21] mentioned that the kidney had a significant amount of both prostaglandin endoperoxide synthase and mixed-function oxidase system enzymes. These were two enzyme systems that had the potential to metabolically activate innocuous drugs into toxic metabolites which bind to critical cellular macromolecules and ultimately resulted in necrosis of the kidney tissue. Podocyte injury with retraction and fusion of foot processes observed in this study might be explained by a study [22] who reported that podocyte foot processes have a role in selective permeability of glomeruli so their injury in kidney disease is usually associated with proteinuria, increase in serum creatinine and urea. Some researchers [23] mentioned a significant, progressive increase in serum creatinine and urea values in patient after topiramate treatment.

In this study, it was observed that the proximal tubules were affected more than the distal ones by topiramate. This was explained by some authors by the fact that PCTs are the first to encounter the toxic agents after their filtration by glomeruli [24] Topiramate resulted in tubular cell vacuolation with distorted microvilli, swollen mitochondria, and an increased number of lysosomes. These findings could be explained by Robbins et al. [25] as vacuolation might be a part of a cellular defense mechanism against injurious substances which were segregated in the form of vacuoles, thereby preventing their interference with cellular metabolism. Furthermore, lysosomal accumulation is an indicator of cellular injury [20]. This tubular affection in this study was confirmed by the result of high levels of serum indoxyl sulfate and lipocalin. These findings agreed with some researchers [26] and [27] who mentioned that damage and failure of the kidney cells resulted in an accumulation of solutes, such as indoxyl sulfate and lipocalin in the blood. Lipocalin identified as the earliest detected serum protein after toxic kidney injury.

In the current study, the presence of cellular debris inside the lumen of the tubules could be explained by a study [28] who found deposition of polymorphic irregular crystals in the dilated proximal tubules associated with a reduction in antioxidant enzyme activity and increased MDA activity suggesting the involvement of oxidative stress in topiramate nephrolithiasis. As explained previously, Alwin and Arthur, [29] stated that some drugs are predisposed to crystal deposition and can result in urolithiasis and obstructive changes. Our findings corroborated the finding of Wasserstein et al. [30], who reported that one of the clinically relevant adverse effects of topiramate is nephrolithiasis, with a reported incidence of $1.5 \%$.

In contrast to the results of this study, some researchers [31] reported that long-term use of antiepileptic drugs increased the risk of atherosclerosis without significant affection of renal functions. Salek et al., [32] also found insignificant differences in serum creatinine and urea after topiramate treatment at a dose of $200 \mathrm{mg}$ for six years.

Regarding this study, topiramate use resulted in MDA elevation with low levels of oxidative stress markers, renal SOD, and CAT which could be attributed to oxidative stress. This opinion is in line with [33] who also demonstrated that topiramate significantly diminished CAT and SOD and significantly increased the level of MDA indicating oxidative stress and lipid peroxidation. The exact mechanism by which topiramate induces nephrotoxicity is not fully clear. During excretion, topiramate lowers serum bicarbonate levels, leading to an elevated urine $\mathrm{pH}$ level, favoring the conditions that cause stones formation [34]. Topiramate acts by blockading voltage-gated sodium and calcium channels through inhibition of carbonic anhydrase II and IV [35] . Carbonic anhydrase inhibition and metabolic acidosis increased the production of reactive oxygen species [36]. Stone formation is associated with high oxidative stress and renal tubular damage. In patient with long-term topiramate therapy, the incidence of renal stones is estimated to be $1.5 \%$ [37].

Administration of vitamin $\mathrm{C}$ to topiramate treated rats efficiently alleviates the nephrotoxicity induced by topiramate. This was obviously showed by the biochemical, histological, and ultrastructural improvement of the kidney tissues. The protective effect of vitamin C could be attributed to its ability to inhibit of lipid peroxidation and attenuation of oxidative stress as evidenced by a study [38] who found that renal degeneration was reduced after treatment with vitamin $\mathrm{C}$ and they suggested that vitamin $C$ can diminish kidney injury induced by acetaminophen. Vitamin $\mathrm{C}$ exhibits antioxidative activity either due to the prevention of the formation of reactive oxygen species or by removing them before damage to vital cell components occurs $[39,40]$

Moreover, our results indicated that vitamin C significantly decreased serum urea, creatinine, lipocalin and indoxyl sulphate in topiramate-treated rats. Vitamin $\mathrm{C}$ also caused a significant increase in antioxidant enzymes (SOD \& CAT) and a significant decrease in MDA. These findings agree 
with study [41] who showed that the administration of vitamin $\mathrm{C}$ can ameliorate the renal toxicity of heavy metals and significantly decreased serum urea and creatinine in rabbits. Additionally, some researchers [42] investigated the protective effects of vitamin $\mathrm{C}$ against carbon tetrachloride induced nephrotoxicity in rats. They found that vitamin C caused a significant decrease in the serum levels of urea \& creatinine and a significant increase in antioxidants enzymes (SOD and CAT). Ozturk et al. [43] reported that vitamin $C$ serves as a prophylactic agent against renal damage with significant decreased serum urea, creatinine, and lipocalin in rats. Vitamin $\mathrm{C}$ also caused significant increases in total antioxidant capacity [44]. However, in contrary to the results of the present study, another work by [45] showed that administration of 250 $\mathrm{mg}$ of vitamin C, three times per week for 8 weeks, caused insignificant changes in serum urea and creatinine. This contradiction may be explained by that their study was carried out in patients with end-stage renal failure.

Conclusion, the biochemical, histological, and ultrastructural findings of the present study verify nephrotoxicity may develop with topiramate which may require dose adjustment to avoid drug accumulation and nephrotoxicity. Further investigations are necessary to explain the actual mechanism of topiramate nephrolithiasis. In addition, vitamin C has a marked role in protection against topiramateinduced nephrotoxicity.

\section{Declaration of conflicts of interest:}

No conflicts of interest.

\section{Funding details:}

This research did not receive any specific grant from funding agencies in the public, commercial, or not-for-profit sectors

Acknowledgements: nil.

\section{References}

1- BENSALEM M.K. and FAKHOURY T.A.: Topiramate and Status Epilepticus: Report of Three Cases. Epilepsy Behav, 4 (6): 757-60, 2003.

2- MARCOTTE D.: Use of Topiramate: A new antiepileptic drug as a mood stabilizer. J. Aff. Disord., 50: 245-2513. 1998.

3- DRODGE W.: Free radicals in the physiological control of cell function. Physiol. Rev., 82: 47, 2001.

4- FOYER C.: Ascorbic acid. In: Alscher R.G., Hess J.L., eds. Antioxidants in higher plants. Boca Raton: CRC Press, pp 31-58, 1993.

5- SIES H.: Oxidative stress: Oxidants and antioxidants. Exp. Physiol., 82: 291-5, 1997.
6- ASADA K.: Ascorbate peroxidase-hydrogenperoxidescavenging enzyme in plants. Physiol. Plant, 85: 235-41, 1992.

7- SINHA S.P. and BOSE S.: Effect of dietary concentration of aflatoxin $\mathrm{Bl}$ and vitamin $\mathrm{C}$ on meiotic chromosomes, sperm morphology and sperm count in mice." Mus Musculus Cytologia, 57: 75-80, 1992.

8- PAGET G.C. and BARNES J.M.: Toxicity in Evaluation of the Drug Activities 1 st ed. Laurence, D.R. and Bacharach, A.L. Academic Press, London, New York, pp. 113, 1964.

9- PORTER RJ., MELDRUM BS. In: Antiseizure Drugs. Basic \& clinical pharmacology. 12th ed. Katzung BG, Masters SB, Trevor AJ, editors. New Delhi: Tata McGrawHill, pp. 409-19, 2012.

10- BANCROFT J. and GAMBLE M.: Theory and practice of histological techniques. 5 th. ed Chruchill Livingstone, London, New York \& Sydney, pp. 377-694, 2002.

11-WEAKLEY B.: Beginner's Handbook in Biological Transmission Electron Microscopy 2 nd ed Churchill Livingstone London, 1981.

12- RODRIGUES W.F., MIGUELI C.B., NAPIMOGA M.H., OLIVEIRA C., et al.: Establishing standards for studying renal function in mice through measurements of body size-adjusted creatinine and urea levels. BioMed, research international, 872827 (8), 2014.

13- MIYAZAKI T., AOYAMA I., ISE M., SEO H. and NIWA T.: An oral sorbent reduces overload of indoxyl sulphate and gene expression of TGF- 31 in uraemic rat kidneys Nephrology Dialysis Transplantation, 15 (11): 1773-1781, 2000.

14- LANDR $\varnothing$ L., DAMÅS J.K., FLO T.H., HEGGELUND L., et al.: Decreased serum lipocalin-2 levels in human immunodeficiency virus-infected patients: Increase during highly active anti-retroviral therapy, Clin. Exp. Immunol., 152 (57-63), 2008.

15- ERDELMEIER I.: Reactions of N-methyl-2-phenlindole with malondialdehyde and 4-hydroxyalkenals. Mechanistic aspects of the colorimetric assay of lipid peroxidation, Chem. Res. Toxicol., 11: 1184-1194, 1997.

16-ADACHI T., OHTA H., YAMADA H., et al.: Quantitative analysis of extracellular-superoxide dismutase in serum and urine by ELISA with monoclonal antibody. Clinica chimica acta, 212 (3): 89-102, 1992.

17- AEBI H.: Catalase in vitro. Methods Enzymol., 105: 121126, 1984

18- ALAN B. and DUNCAN C.: Quantitative data analysis with IBM SPSS 17, 18 and 19: A guide for social scientists. New York, NY: Routledge, pp. 323-348, 2012.

19- EL MAKAWY A.I., MABROUK D.M., IBRAHIM F.M. et al.: Genotoxic, biochemical and histopathological studies to assessment the topiramate hepatorenal toxicity in mice. Drug and Chemical Toxicology, 1-10, 2019.

20- HOTTA O., INOUE C.N., MIYABAYASHI S., et al. Clinical and pathological features of focal segmental glomerulosclerosis with mitochondrial TRNAeu (UUR) gene mutation. Kidney Int., 59: 1236-1243, 2001.

21- GIBSON G.G. and SKETT P.: Pharmacological and toxicological aspects of drug metabolism. Introduction 
to Drug Metabolism. ${ }^{2 n d}$ ed. Boston, MA: Springer US, p. 170-8, 1994.

22- OLSEN S. and SOLEZ K.: Acute tubular necrosis and toxic renal injury. In:Tisher C.C., Brenner B.M. Renal pathology with clinical and functional correlations. 2 nd ed. Philadelphia: JB Lippincott, pp. 769-809, 1994.

23- FERRIOLS L.R., HERAS J.A., SANZ MUNOZ M., et al.: Acute renal failure probably associated with topiramate. Farm Hosp., 27 (2): 105-8, 2003.

24- LECHNER J., KRALL M. and NETZER A.: Effects of interferon alpha-2b on barrier function and junctional complexes of renal proximal tubular LLC-PK1 cells. Kidney Int., 55: 2178-2191, 1999.

25- ROBBINS S.L., CORTAN R.S. and KUMAR V.: Pathologic basis of disease. 9 th ed.: WB Sunders Company; Canada, 2011.

26- LEONG S.C. and SIRICH T.L.: Indoxyl sulfate review of toxicity and therapeutic strategies. Toxins., 8 (12): 358 , 2016.

27- LI D., SUN W.Y., FU B., et al.: Lipocalin-2 the myth of its expression and function. Basic \& clinical pharmacology \& toxicology, 127: 142-151, 2020.

28- JOHN P. and ANITHA L.: Nephrolithiatic Potential of Topiramate in Male Albino Rats. Asian Journal of Research in Pharmaceutical Sciences and Biotechnology, 3 (4): $93-$ 100,2015

29- ALWIN H.L. and ARTHUR H.C.: Drug-induced kidney disease-Pathology and Current Concepts. Ann. Acad. Med Singapore, 38: 240-250, 2009.

30- WASSERSTEIN A.G., RAK I. and REIFE R.A.: Nephrolithiasis during treatment with topiramate (abstract). Epilepsia, 36 (Suppl. 3): S153. 32, 1995.

31- RADEEF M.Y. and AL-SHAMMA K.: The Effect of Treatment with Antiepileptic Drugs (Carbamazepine, Valproic Acid, Topiramate, and Their Combination) On Lipid Profile, C-Reactive Protein, and Renal Function in Iraqi Epileptic Patients. Tikrit Journal of Pharmaceutical Sciences, 9 (1): 1-18, 2013.

32- SALEK T., ANDEL I. and KURFURSTOVA I.: Topiramate induced metabolic acidosis and kidney stones a case study. Biochemia Medica., 27 (2): 404-410, 2017.

33- AGARWAL N.B., AGARWAL N.K., MEDIRATTA P.K., et al.: Effect of lamotrigine, oxcarbazepine and topiramate on cognitive functions and oxidative stress in PTZ-kindled mice. Seizure, 20: 257-262, 2011.
34- WELCH B.J., GRAYBEAL D. and MOE O.W.: Biochemical and stone-risk profiles with topiramate treatment. Am. J. Kidney Dis., 48 (4): 555-63, 2006.

35- VEGA D., MAALOUF N.M. and SAKHAEE K.: Increased propensity for calcium phosphate kidney stones with topiramate use. Expert. Opin. Drug. Saf., 6: 547-557, 2007.

36- RATKAL J.M. and SHARMA E.: Risk of urolithiasis due to topiramate as weight loss drug. International Journal of Surgery, 3 (1): 77-78, 2019.

37- MATLAGA B.R., SHAH O.D. and ASSIMOS D.G.: Druginduced urinary calculi. Rev. Urol., 5: 227-31, 2003.

38- ADENEYE A.A. and OLOGUNJU J.O.: Protective effect of oral ascorbic acid (vitamin C) on acetaminophen induced renal injuries in the rat. African J. Biomed. Res., 12 (1): 11-21, 2009.

39- LOEWUS F.A.: Ascorbic acid and its metabolic products. In: Preiss J., ed. The biochemistry of plants. New York: Academic Press, 14: 85-107, 1988.

40- RHEE S.G.: Cell signaling. H2O2, a necessary evil for cell signaling. Science, 312: 1882-3, 2006.

41- ALI S., HUSSAIN S., KHAN R., et al.: Renal toxicity of heavy metals (cadmium and mercury) and their amelioration with ascorbic acid in rabbits. Environmental Science and Pollution Research, 26 (4): 3909-3920, 2019.

42- RAHMOUNI F., BADRAOUI R., AMRI N., et al.: Hepatotoxicity and nephrotoxicity in rats induced by carbon tetrachloride and the protective effects of Teucrium polium and vitamin C. Toxicology mechanisms and methods, 29 (5): 313-321, 2019.

43- OZTURK O., USTEBAY S., EROGLU H.A., et al.: An experimental study of ascorbic acid effects in acute renal failure under general anesthesia. Acta. cirurgica. brasileira, 32 (10): 853-861, 2017.

44- APRIOKU J. and OBIANIME A.: Comparative and interactive studies of aqueous leaf extracts of Ocimum gratissimum Linn. (Lamiaeceae), Vitamins $\mathrm{C}$ and $\mathrm{E}$ on the basal serum phosphatase levels of male guinea pigs. West Afr. J. Pharmacol. Drug Res., 24: 35-41, 2008.

45- BINIAZ V., TAYEBI A., EBADI A., et al.: Effect of vitamin $C$ supplementation on serum uric acid in patients undergoing hemodialysis: A randomized controlled trial. Iranian journal of kidney diseases, 8 (5): 401-407, 2014. 


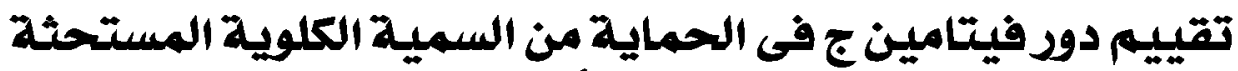

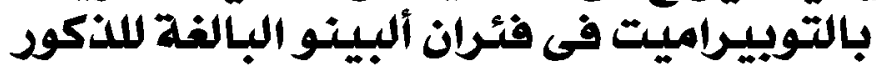

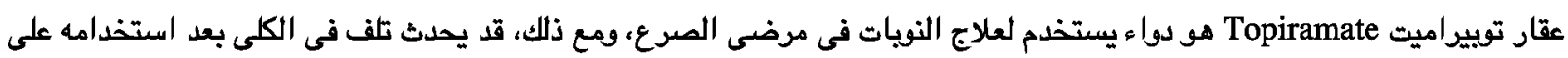
المدى الطويل. تتنوع آليات الضرد ويمكن أن تئّثر على جميع المكونات الخلوية الكلوية. هدف الدراسة: العلاج بمضادات الاكسدة، مثل فيتامين سى، قد يساعد في منع هذا التلف الكلهى. فى هذه الدئه الدراسة، استخدمنا الأساليب

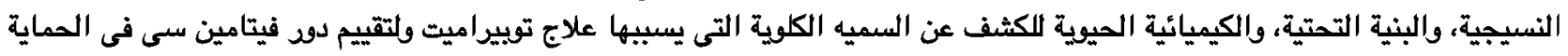
ضد السمية الكلوية التى يسبيها التوبيراميتية.

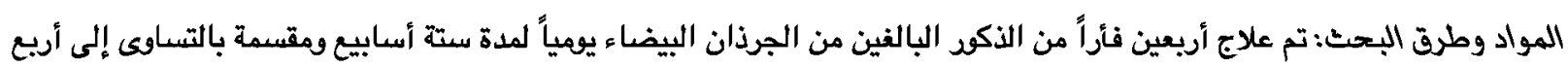

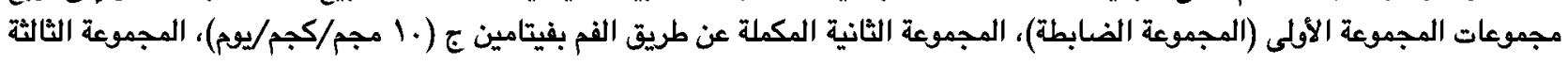

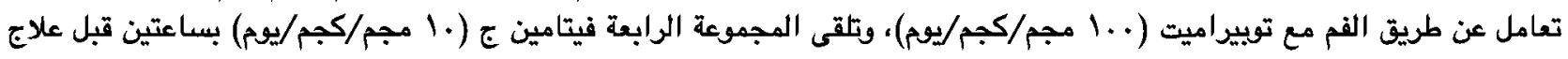

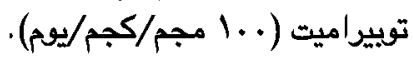

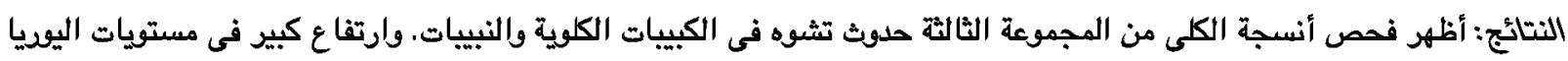

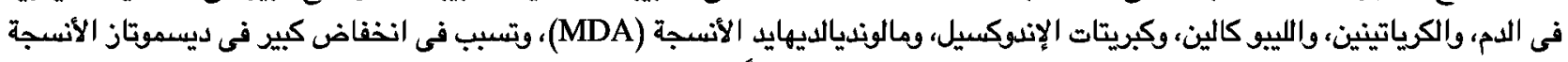

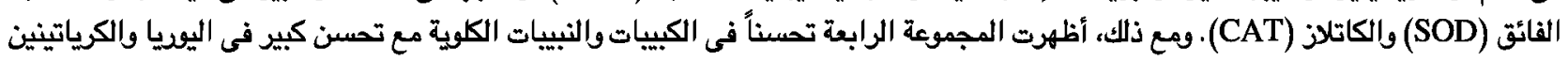

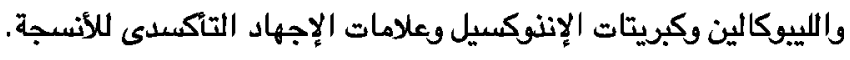

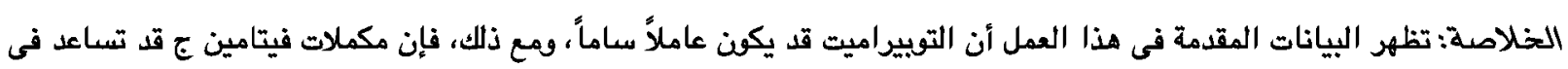
الحماية من السمية الكلوية التى يسبيها التوبيراميت. 